\title{
Surface Friction on Pullout Capacity of Pile in Sandy Soil
}

\author{
P. Dayakar, K. Venkat Raman, R.Venkatakrishnaiah
}

\begin{abstract}
At the point when structures are built underneath the ground water table or in the event that they are developed submerged, elevate powers are to be applied on the storm cellar of structures. Likewise on account of transmission line towers, securing frameworks for sea surface or submerged stages, tall stacks and so on are generally exposed to upsetting minutes because of wind, wave weight or ship sway and so forth. These upsetting minutes are moved to structures establishment as pressure on certain components and pullout on others. For establishments in such structures, typically a blend of vertical and hitter heaps is utilized. A huge scale exploratory program utilizing vertical model heaps (Cement Mortar heaps) in sand exposed to pullout loads has been done in a model tank of size $25 \mathrm{~cm} x 25 \mathrm{~cm} x$ $25 \mathrm{~cm}$. Gentle steel of $8 \mathrm{~mm}$ measurement is utilized for safe haven reason. PVC funnels of changing breadths, lengths, are utilized for throwing of model heaps. An inadequately reviewed stream sand having explicit gravity $G=2.61$, Uniformity coefficient $=$ 3.62 , ebb and flow coefficient $=0.91$ has been utilized as establishment medium. It is to watch the conduct of sand when heap is exposed to pullout limit. Likewise the pullout limit of heap is resolved with various length to distance across proportions on sand.
\end{abstract}

Keywords - Pullout Capacity, Model Piles, Sand bed, Vertical piles, Pile roughness

\section{INTRODUCTION}

There are many structures which are subjected to uplift, tensile and compressive forces. The structures subjected to these forces include pipeline anchors, radar towers, excavation bracings, suspension bridges, offshore structures, etc[1]-[5]. Many researches have been carried out on piles subjected to pull-out in cohesion-less soil of varying densities.

Various speculations with respect to conduct of heaps under various stacking conditions have been created throughout the years. The dependability of the hypotheses can be exhibited uniquely by correlation of test results on display or field heaps with the hypothetical forecasts[6]-[10]. Full-scale field tests, however profoundly alluring, are commonly costly and hard to perform. Without assets and extent of testing model little scale research center model test led on heaps in establishment medium arranged under controlled condition may fill the need somewhat.

Revised Manuscript Received on October 22, 2019.

P. Dayakar, Department of Civil Engineering, Bharath Institute of Higher Education and Research, Chennai , India. Email: dayakarpitti@yahoo.co.in

K. Venkat Raman, Department of Civil Engineering, Bharath Institute of Higher Education and Research, Chennai , India. Email: venkatraman.civil@bharathuniv.ac.in

R.Venkatakrishnaiah, Department of Civil Engineering, Bharath Institute of Higher Education and Research, Chennai, India. Email: venkatapec@gmail.com
Appropriately directed research center tests, with realized parameters influencing the dirt heap reaction under pulling burdens would give data on subjective and quantitative commitments of such parameters on extreme obstruction of heaps without field test results[31]-[34]. Compared to previous studies in this area, this investigation proposes to consider wider range of parameters and their effects on the uplift capacity of piles.

Pile-soil interaction problem is very complicated. The phenomenon is a function of pile material, its surface characteristics, length, diameter, soil-pile friction angle, geometry of group, methods of installation and end conditions, soil characteristics like consistency, compactness, stratification, consolidation, sensitivity, drainage conditions, dissipation of excess pore pressures and shear parameters, location of water table and type of loading. Extensive theoretical and experimental investigations are available on the behavior of piles and pile groups subjected to axial, inclined or lateral compressive loads[11]-[15]. They relate to load carrying capacity of the piles/pile groups, load-displacement response, buckling etc. Consequently the design and analysis of piles under these loading conditions can be done with greater assurance and economy under normal operating conditions.

\section{METHODOLOGY}

\section{A.Soil properties}

Various tests have been performed on soil, details of which are mentioned as below;

Table 1: Properties of Soil

\begin{tabular}{|c|c|c|c|c|c|}
\hline $\mathrm{S}_{\mathrm{N} \mathrm{N}_{0} \text {. }}$ & Name of Test & Symbol & \begin{tabular}{|ll} 
State & of \\
Soil &
\end{tabular} & Values & Units \\
\hline 1 & SPECIFIC GRAVITY OF SOIL & G & LOOSE & 2.61 & Unitless \\
\hline 2 & GRAIN SIZE DISTRIBUTION & $\begin{array}{l}C_{U} \\
C_{c}\end{array}$ & LOOSE & $\begin{array}{l}3.16 \\
0.91\end{array}$ & Unitless \\
\hline 3 & COMPACTION OF SOIL & $\begin{array}{l}\text { ydmax } \\
\text { OMC }\end{array}$ & DENSE & $\begin{array}{l}1.832 \\
11.9\end{array}$ & $\begin{array}{l}\mathrm{g} / \mathrm{cC} \\
\%\end{array}$ \\
\hline 4 & RELATIVE DENSITY & $R_{d}$ & $\begin{array}{l}\text { LOOSE \& } \\
\text { DENSE }\end{array}$ & 44.44 & $\%$ \\
\hline 5 & DIRECT SHEAR TEST & $\begin{array}{l}\Phi \\
\delta \\
\end{array}$ & LOOSE & $\begin{array}{l}33.97 \\
37.56 \\
\end{array}$ & Degrees \\
\hline
\end{tabular}

B. Casting of shear box specimens

Shear box specimens of size $6 \mathrm{~cm} \times 6 \mathrm{~cm}$ are casted using pile material (cement and sand) in order to determine the exact pile-soil friction angle (delta) which is responsible for load transfer through skin friction when pile is subjected to loading. 


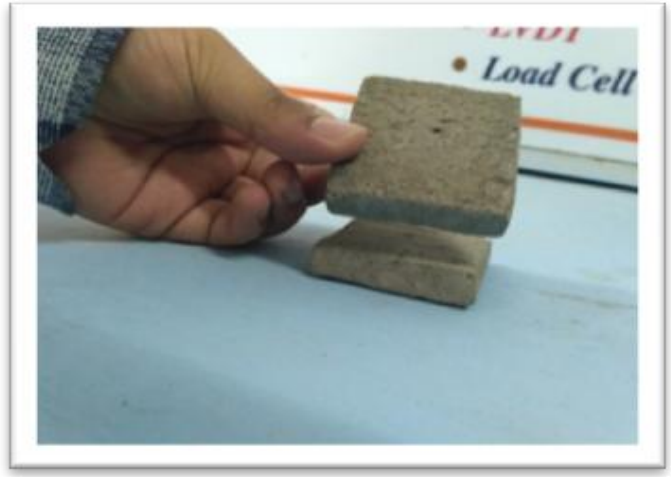

Figure - 1 Casted specimen

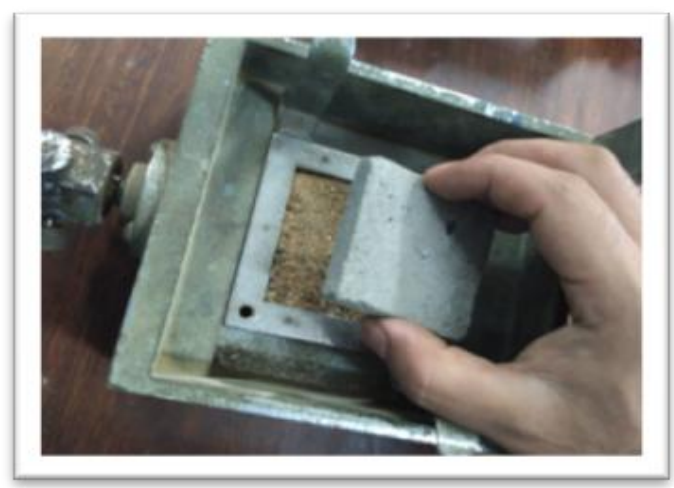

Figure - 2 Interface $b / w$ sand and specimen

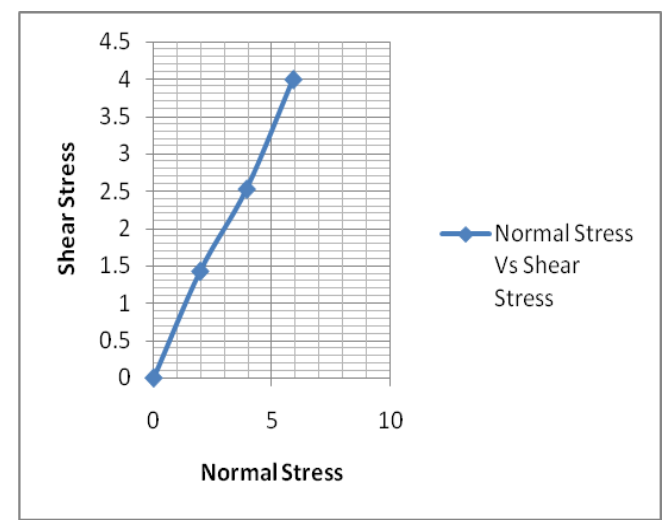

Figure -3 Determination of $\varphi$ for sand

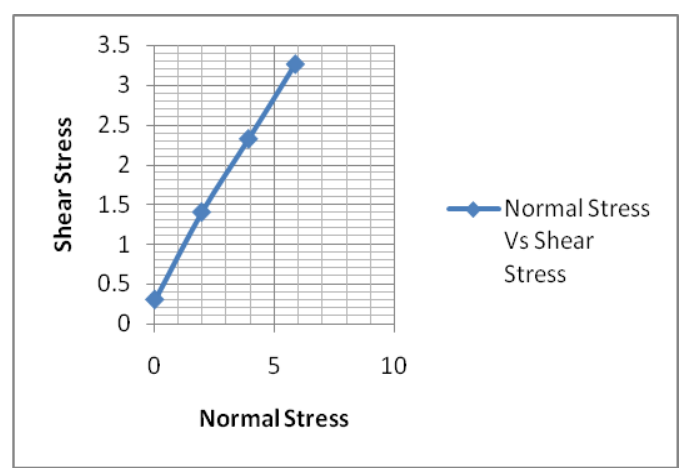

Figure - 4 Determination of friction $b / w$ sand and pile material

i) Internal angle of friction, $\varphi=33.96$

ii) Soil pile friction angle, $\delta=37.56$

\section{Casting of model piles}

Cement mortar piles of different lengths are casted using a hollow pipe (PVC pipe). Pipe of required length and diameter is cut. Mosquito net is being used to make the pile surface rough. A $6 \mathrm{~mm}$ diameter bar is placed in the centre of pipe with sufficient allowance length at the top which is then rigidly fixed with the load cell when pile is subjected to pullout[16]-[20]. To determine the pullout capacity of piles in sandy soils, model piles of different parameters are casted and are mentioned as follows.

i) Length of pile $=17 \mathrm{~cm}$, diameter $=3.75 \mathrm{~cm}, \mathrm{~L} / \mathrm{D}=4.5$

ii) Length of pile $=15 \mathrm{~cm}$, diameter $=3.75 \mathrm{~cm}, \mathrm{~L} / \mathrm{D}=4$

iii)Pile with smooth surface

iv) Pile with rough surface

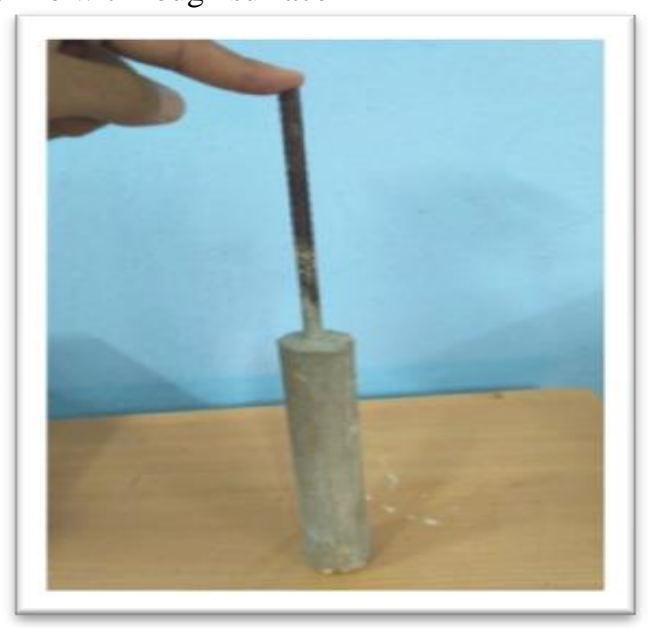

Figure 5- Casted model pile, $\mathrm{L} / \mathrm{D}=\mathbf{4 . 5}$

Pullout capacity test on model pile in loose state, $\mathrm{L} / \mathrm{D}=4.0$

$>$ Pullout capacity test on model pile in medium dense state, $\mathrm{L} / \mathrm{D}=4.0$

$>$ Pullout capacity test on model pile in dense state, $\mathrm{L} / \mathrm{D}=4.0$

$>$ Pullout capacity test on model smooth pile

$>$ Pullout capacity test on model rough pile[21]-[24]

\section{RESULTS AND DISCUSSION}

1. In loose state with $\mathrm{L} / \mathrm{D}=4.5$

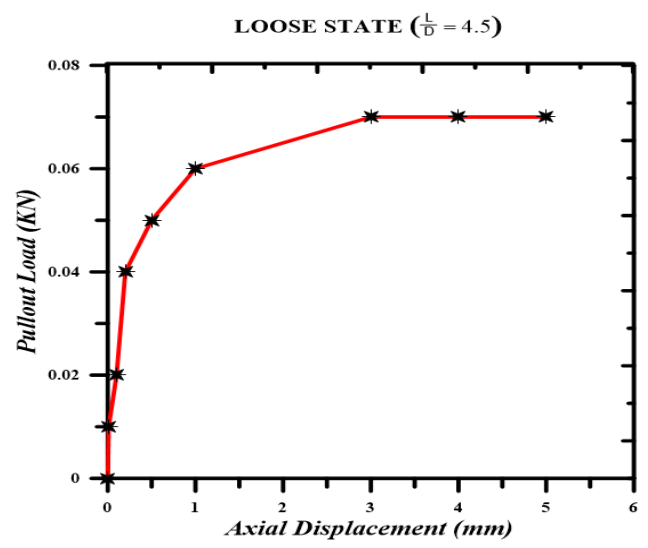

2. In medium dense state with $\mathrm{L} / \mathrm{D}=4.5$ 


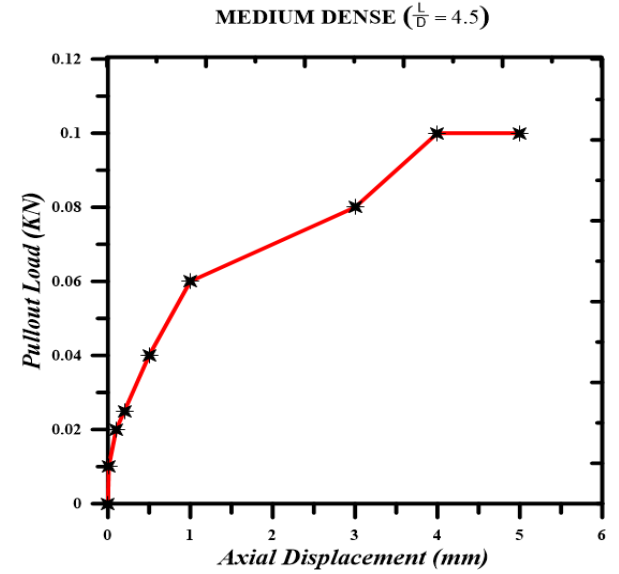

3. In dense state with $\mathrm{L} / \mathrm{D}=4.5$

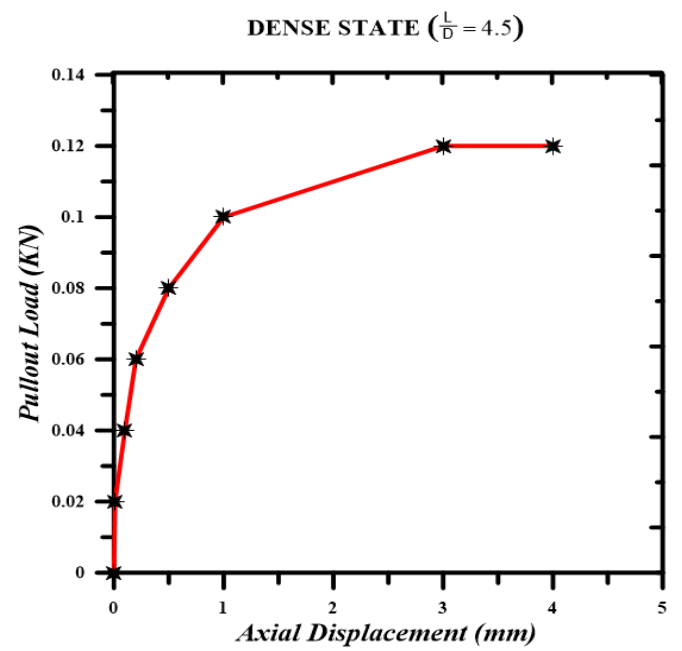

4. In loose state with $\mathrm{L} / \mathrm{D}=4.0$

LOOSE STATE $\left(\frac{L}{D}=4\right)$

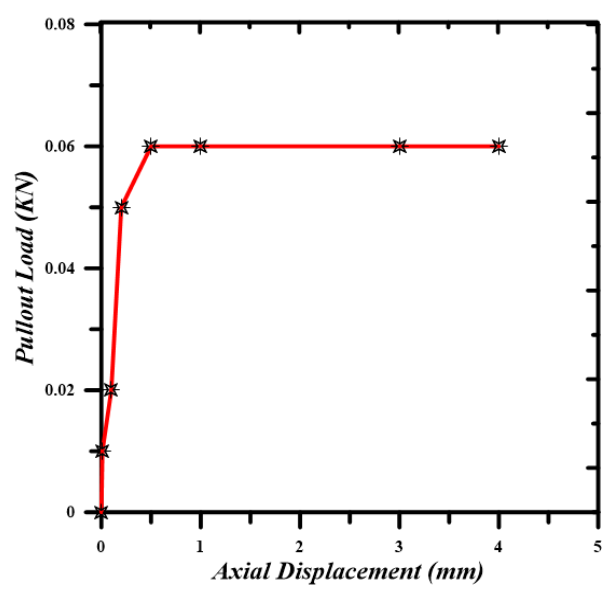

5. In medium dense state, $\mathrm{L} / \mathrm{D}=4.0$

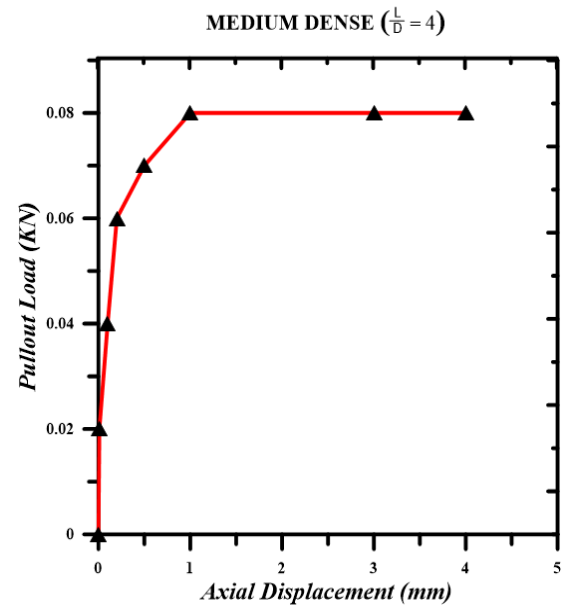

6. In dense state, $\mathrm{L} / \mathrm{D}=4.0$

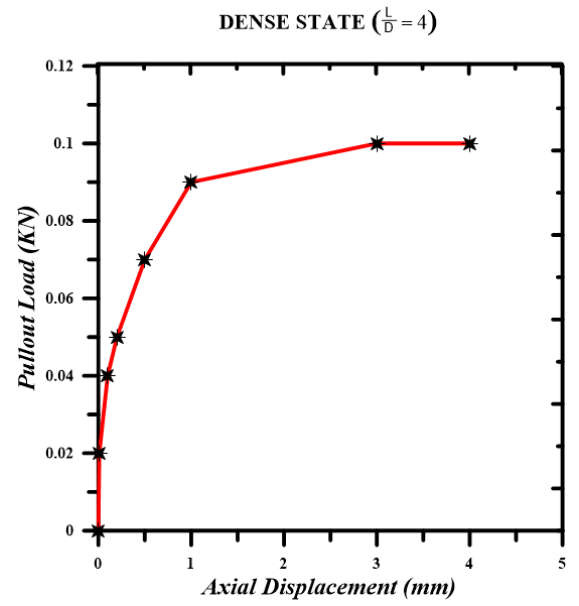

7. Comparison of $\mathrm{L} / \mathrm{D}=4.5$ with $\mathrm{L} / \mathrm{D}=4.0$

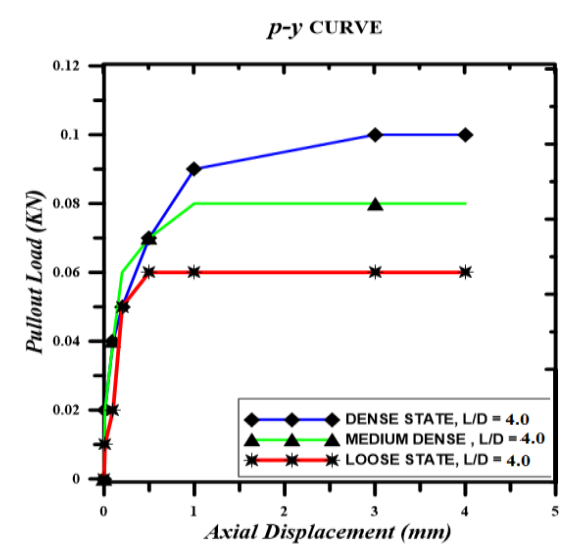




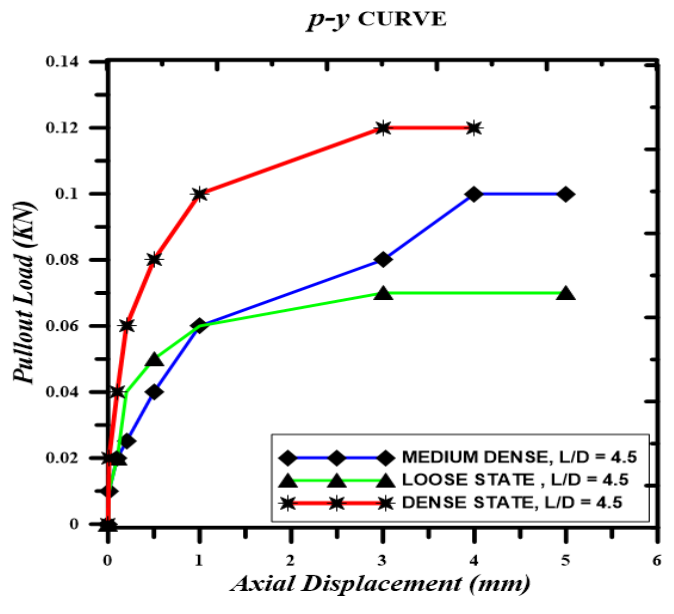

$\mathrm{L} / \mathrm{D}=4.5$

8. Comparison of pullout capacity of pile in different soil states

\begin{tabular}{|l|l|l|l|l|l|l|}
\hline & \multicolumn{2}{|l|}{ L/D=4.0 } & \multicolumn{2}{l|}{ LD $=4.5$} \\
\hline & LOOSE & MEDICM & DENSE & LOOSE & MEDICM & DENSE \\
\hline $\begin{array}{l}\text { PULLOUT } \\
\text { LOAD (kN) }\end{array}$ & 0.06 & 0.08 & 0.1 & 0.07 & 0.1 & 0.12 \\
\hline $\begin{array}{l}\text { \%age } \\
\text { INCREASE }\end{array}$ & 0 & 33.33 & 66.66 & 0 & 42.85 & 71.42 \\
\hline
\end{tabular}

9. Influence of surface characteristics

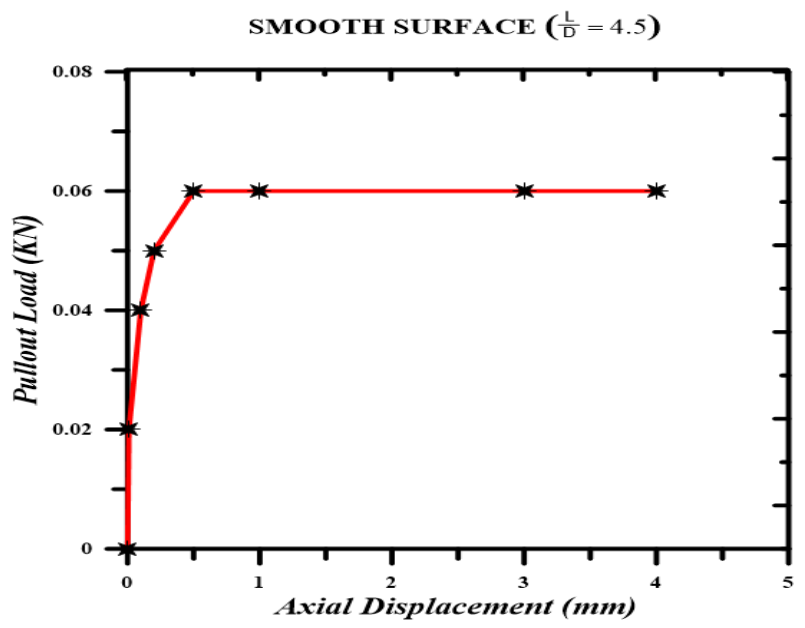

Smooth Surface

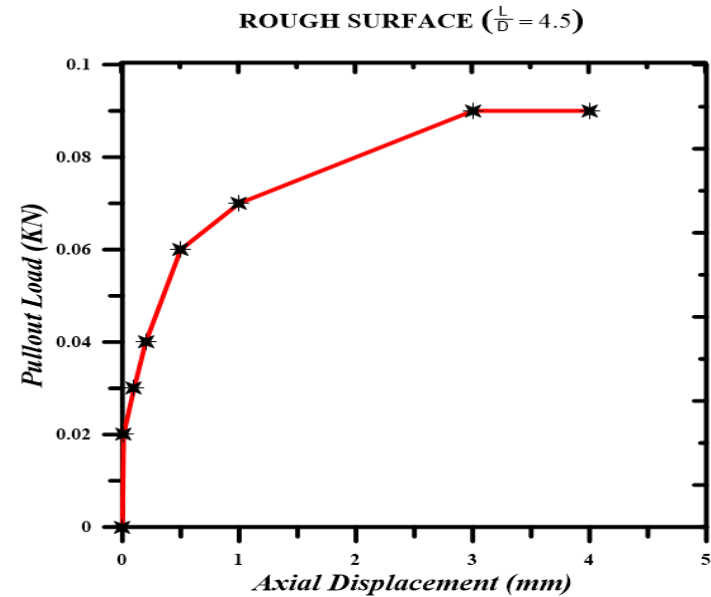

Rough Surface

\section{CONCLUSION}

From the laboratory investigations that have been carried out, the following conclusions are drawn;

Axial pullout load versus hub dislodging outlines for vertical heaps are basically straight at starting phases of stacking and non-direct at later stages.

Pullout limit of heap is seen as additional in thick state contrasted with medium and free state[25]-[30].

The pullout limit of heap in thick state with $\mathrm{L} / \mathrm{d}=4.0$ is found to have $66.66 \%$ expanded contrasted with its free state.

The pullout limit of heap in thick state with $\mathrm{L} / \mathrm{d}=4.5$ is found to have $71.42 \%$ expanded contrasted with its free state.

The opposition offered by the heap at any pivotal dislodging increments altogether with increment in surface unpleasantness.

The obstruction offered by the heap at any hub uprooting increments altogether with increment in $\mathrm{L} / \mathrm{d}$ proportion.

\section{REFERENCES}

1. Iyappan L., Dayakar P., Identification of landslide prone zone for coonoortalukusing spatial technology, International Journal of Applied Engineering Research,V-9,I-22,PP-5724-5732,Y-2014.

2. Kumar J., Sathish Kumar K., Dayakar P.,Effect of microsilica on high strength concrete, International Journal of Applied Engineering Research,V-9,I-22,PP-5427-5432,Y-2014.

3. Dayakar P., Vijay Ruthrapathi G., Prakesh J., Management of bio-medical waste, International Journal of Applied Engineering Research,V-9,I-22,PP-5518-5526,Y-2014.

4. Swaminathan N., Dayakar P., Resource optimization in construction project, International Journal of Applied Engineering Research,V-9,I-22,PP-5546-5551,Y-2014.

5. Venkat Raman K., Dayakar P., Raju K.V.B.,An experimental study on effect of cone diameters in penetration test on sandy soil, International Journal of Civil Engineering and Technology,V-8,I-8,PP-1581-1588,Y-2017.

6. Saritha B., Chockalingam M.P.,Photodradation of malachite green DYE using TIO2/activated carbon composite,International Journal of Civil Engineering and Technology,V-8,I-8,PP-156-163,Y-2017

7. Shendge R.B., Chockalingam M.P., Saritha B., Ambica A.,Swat modelling for sediment yield: A case study of Ujjani reservoir in Maharashtra, India,International Journal of Civil Engineering and Technology,V-9,I-1,PP-245-252,Y-2018

8. Chockalingam M.P., Balamurgan V.,Modernisation of an existing urban road-sector in Chennai, a case study 
report,International Journal of Civil Engineering and Technology,V-8,I-8,PP-1457-1467,Y-2017

9. Saritha B., Chockalingam M.P.,Adsorption study on removal of basic dye by modified coconut shell adsorbent, International Journal of Civil Engineering and Technology,V-8,I-8,PP-1370-1374,Y-2017

10. Saritha B., Chockalingam M.P.,Adsorptive removal of heavy metal chromium from aqueous medium using modified natural adsorbent,International Journal of Civil Engineering and Technology,V-8,I-8,PP-1382-1387,Y-2017

11. Chockalingam M.P., Palanivelraja S.,Retrospective analysis of a theoretical model used for forecasting future air quality near the north Chennai thermal power plant,International Journal of Civil Engineering and Technology,V-8,I-8,PP-1457-1467,Y-2017

12. Saritha B., Chockalingam M.P.,Photodegradation of methylene blue dye in aqueous medium by $\mathrm{Fe}-\mathrm{AC} / \mathrm{TiO} 2$ Composite,Nature Environment and Pollution Technology,V-17,I-4,PP-1259-1265,Y-2018

13. Shendge R.B., Chockalingam M.P., Kaviya B., Ambica A.,Estimates of potential evapotranspiration rates by three methods in upper Bhima Basin, In Maharashtra, India,International Journal of Civil Engineering and Technology,V-9,I-2,PP-475-480,Y-2018

14. Shendge R.B., Chockalingam M.P.,The soil and water assessment tool for Ujjani Reservoir,International Journal of Mechanical Engineering and Technology,V-9,I-2,PP-354-359,Y-2018

15. Shendge R.B., Chockalingam M.P.,A review on soil and water assessment tool,International Journal of Mechanical Engineering and Technology,V-9,I-2,PP-347-353,Y-2018

16. Sachithanandam P., Meikandaan T.P., Srividya T.,Steel framed multi storey residential building analysis and design,International Journa of Applied Engineering Research,V-9,I-22,PP-5527-5529,Y-2014

17. Meikandaan T.P., Ramachandra Murthy A.,Study of damaged RC beams repaired by bonding of CFRP laminates,International Journal of Civil Engineering and Technology,V-8,I-2,PP-470-486,Y-2017

18. Meikandaan T.P., Ramachandra Murthy A.,Retrofittng of reinforced concrete beams using GFRP overlays,International Journal of Civil Engineering and Technology,V-8,I-2,PP-423-439,Y-2017

19. Meikandaan T.P., Ramachandra Murthy A.,Flexural behaviour of RC beam wrapped with GFRP sheets,International Journal of Civil Engineering and Technology,V-8,I-2,PP-452-469,Y-2017

20. Meikandaan T.P., Murthy A.R.,Experimental study on strengthening of rc beams using glass Fiber,International Journal of Civil Engineering and Technology,V-9,I-11,PP-959-965,Y-2018

21. Meikandaan T.P., Hemapriya M.,Use of glass FRP sheets as external flexural reinforcement in RCC Beam,International Journal of Civil Engineering and Technology,V-8,I-8,PP-1485-1501,Y-2017

22. Saraswathy R., Saritha B.,Planning of integrated satellite township at Thirumazhisai,International Journal of Applied Engineering Research,V-9,I-22,PP-5558-5560,Y-2014

23. Saritha B., Ilayaraja K., Eqyaabal Z.,Geo textiles and geo synthetics for soil reinforcement,International Journal of Applied Engineering Research,V-9,I-22,PP-5533-5536,Y-2014

24. Ambica A., Saritha B., Changring G., Singh N B., Rajen M., Salman Md.,Analysis of groundwater quality in and around Tambaram taluk, Kancheepuram district,International Journal of Civil Engineering and Technology,V-8,I-8,PP-1362-1369,Y-2017

25. Arunya A., Sarayu K., Ramachandra Murthy A., Iyer N.R.,Enhancement of durability properties of bioconcrete incorporated with nano silica,International Journal of Civil Engineering and Technology,V-8,I-8,PP-1388-1394,Y-2017

26. Ilayaraja K., Krishnamurthy R.R., Jayaprakash M., Velmurugan P.M., Muthuraj S.,Characterization of the 26 December 2004 tsunami deposits in Andaman Islands (Bay of Bengal, India),Environmental Earth Sciences,V-66,I-8,PP-2459-2476,Y-2012

27. Ilayaraja K.,Morphometric parameters of micro watershed in Paravanar sub-basin, Cuddalore District,International Journal of Civil Engineering and Technology,V-8,I-8,PP-1444-1449,Y-2017

28. Ilayaraja K., Singh R.K., Rana N., Chauhan R., Sutradhar N.,Site suitability assessment for residential areas in south Chennai region using remote sensing and GIS techniques,International Journal of Civil Engineering and Technology,V-8,I-8,PP-1468-1475,Y-2017

29. Ilayaraja K., Reza W., Kumar V., Paul S., Chowdhary R.,Estimation of land surface temperature of Chennai metropolitan area using Landsat images,International Journal of Civil Engineering and Technology,V-8,I-8,PP-1450-1456,Y-2017

30. Chitra R.,Experimental study on beam using steel fiber and latex,International Journal of Civil Engineering and Technology,V-8,I-8,PP-1395-1403,Y-2017
31. Chitra R.,Analysis of traffic and management at Kovilambakkam intersection,International Journal of Civil Engineering and Technology,V-8,I-8,PP-1433-1443,Y-2017

32. Aswathy M.,Experimental study on light weight foamed concrete,International Journal of Civil Engineering and Technology,V-8,I-8,PP-1404-1412,Y-2017

33. Aswathy M.,Wastewater treatment using constructed wetland with water lettuce (Eichornia Crasipies),International Journal of Civil Engineering and Technology,V-8,I-8,PP-1413-1421,Y-2017

34. Kiruthiga K., Anandh K.S., Gunasekaran K, Assessment of influencing factors on improving effectiveness and productivity of construction engineers, 2015, International Journal of Applied Engineering Research, V - 10,I -17,p -13849-13854.

\section{AUTHORS PROFILE}

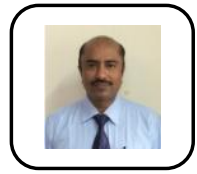

P. Dayakar, Associate Professor, Department of Civil Engineering, Bharath Institute of Higher Education and Research, Chennai, India.

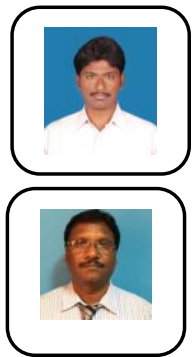

K. Venkat Raman, Assistant Professor, Department of Civil Engineering, Bharath Institute of Higher Education and Research, Chennai, India

R.Venkatakrishnaiah, Associate Professor, Department of Civil Engineering, Bharath Institute of Higher Education and Research, Chennai , India. 